\title{
PD-L2 Expression as a Potential Predictive Biomarker for the Response to Anti-PD-1 Drugs in Patients with Non-small Cell Lung Cancer
}

\author{
SHINKICHI TAKAMORI ${ }^{1}$, KAZUKI TAKADA $^{2}$, GOUJI TOYOKAWA $^{1}$, KOICHI AZUMA $^{3}$, \\ MOTOTSUGU SHIMOKAWA ${ }^{4}$, TOMOKO JOGO ${ }^{1,5}$, YUICHI YAMADA ${ }^{5}$, FUMIHIKO HIRAI $^{1}$, \\ TETSUZO TAGAWA $^{1}$, AKIHIKO KAWAHARA ${ }^{6}$, JUN AKIBA $^{6}$, ISAMU OKAMOTO ${ }^{7}$, \\ YOICHI NAKANISHI ${ }^{7}$, YOSHINAO ODA ${ }^{5}$, TOMOAKI HOSHINO ${ }^{3}$ and YOSHIHIKO MAEHARA ${ }^{1}$ \\ ${ }^{1}$ Department of Surgery and Science, Graduate School of Medical Sciences, Kyushu University, Fukuoka, Japan; \\ ${ }^{2}$ Department of Thoracic Oncology, National Kyushu Cancer Center, Fukuoka, Japan; \\ ${ }^{3}$ Division of Respirology, Neurology, and Rheumatology, \\ Department of Internal Medicine, Kurume University School of Medicine, Fukuoka, Japan; \\ ${ }^{4}$ Clinical Research Institute, National Kyushu Cancer Center, Fukuoka, Japan; \\ ${ }^{5}$ Department of Anatomic Pathology, Graduate School of Medical Sciences, Kyushu University, Fukuoka, Japan; \\ ${ }^{6}$ Department of Diagnostic Pathology, Kurume University School of Medicine, Fukuoka, Japan; \\ ${ }^{7}$ Research Institute for Disease of the Chest, \\ Graduate School of Medical Sciences, Kyushu University, Fukuoka, Japan
}

\begin{abstract}
Background/Aim: To investigate the role of programmed cell death-ligand 2 (PD-L2) expression as a predictive biomarker for response to anti-programmed cell death-1 (PD-1) drugs in patients with non-small cell lung cancer (NSCLC). Patients and Methods: Ten patients who had undergone curative lung resection and received the anti-PD1 drugs for the recurrence were enrolled. The cut-off value for PD-L2 (antibody clone 176611) expression on tumor cells was set at 50\%. Tumor response was evaluated according to immune-related response criteria. Results: Seven patients (70.0\%) were positive for PD-L2. The response rates were $28.6 \%(2 / 7)$ and $33.3 \%$ (1/3) in patients with PD-L2-positive and PD-L2-negative NSCLC, respectively. Disease control was obtained in 2 patients despite the programmed cell deathligand 1 (PD-L1)-negativity (antibody clone 22C3: 0\%, antibody clone SP142:0\%), and these tumors expressed PD$L 2(\geq 1 \%)$. Conclusion: PD-L2 expression may be a target of immunotherapy in patients with PD-L1-negative NSCLC.
\end{abstract}

Correspondence to: Kazuki Takada, Department of Thoracic Oncology, National Kyushu Cancer Center, 3-1-1 Notame, Minamiku, Fukuoka, 811-1347, Japan. Tel: +81 925413231, Fax: +81 925514585, e-mail: k_takada@surg2.med.kyushu-u.ac.jp

Key Words: Programmed cell death-ligand 1, programmed cell death-ligand 2, non-small cell lung cancer.
Lung cancer is one of the most lethal malignancies in the world, and non-small cell lung cancer (NSCLC) accounts for $85 \%$ of cases $(1,2)$. There have been dramatic developments in pharmacotherapy for patients with NSCLC, and immunotherapy targeting programmed cell death 1 (PD-1) or programmed death-ligand 1 (PD-L1) has become one of the standard pharmacological therapies $(3,4)$. Since the anti-PD-1 drugs became a standard therapy for patients with NSCLC, biomarkers predicting the response to anti-PD-1 antibodies are being sought. According to previous reports, PD-L1 expression by tumor cells is one of the promising predictive biomarkers for the response to the immunotherapy (5-8). However, given the results of CheckMate-057 that the overall survival of anti-PD-1 treated patients who were negative for PD-L1 expression e was equivalent to that of patients treated by conventional standard chemotherapy (3), other ligands to PD-1, including programmed death-ligand 2 (PD-L2), may be considered as therapy targets.

PD-L2 protein is expressed mainly by dendritic cells, macrophages, and tumor cells, and down-regulates the effector functions of $\mathrm{T}$ cells via PD-1/PD-L2 axis in the tumor microenvironment $(9,10)$. A recent retrospective study has suggested the relationship between PD-L2 expression and tumor response to anti-PD-1 drugs in patients with human solid tumors (11), but their association in patients with NSCLC is unknown. Therefore, in this translational study, the clinical impact of PD-L2 expression as a predictive biomarker to antiPD-1 antibodies in patients with NSCLC was examined. 
Table I. Patient characteristics $(n=10)$.

\begin{tabular}{|c|c|c|c|c|c|c|c|c|c|c|c|}
\hline Case & Age & Gender & $\begin{array}{l}\text { Histological } \\
\text { type }\end{array}$ & $\begin{array}{l}\text { Target } \\
\text { lesion }\end{array}$ & $\begin{array}{l}\text { PD-L1 } \\
(22 \mathrm{C} 3)\end{array}$ & $\begin{array}{l}\text { PD-L1 } \\
\text { (SP142) }\end{array}$ & $\begin{array}{c}\text { PD-L2 } \\
(176611)\end{array}$ & $\begin{array}{l}\text { Anti-PD-1 } \\
\text { drug }\end{array}$ & $\begin{array}{c}\text { PFS } \\
\text { (months) }\end{array}$ & $\begin{array}{c}\text { Best } \\
\text { Response }\end{array}$ & irRC \\
\hline 1 & 69 & M & $\mathrm{Sq}$ & Liver metastasis & 5 & 0 & 50 & Pembrolizumab & 10.5 & PR & $-78.7 \%$ \\
\hline 2 & 70 & M & $\mathrm{Ad}$ & $\begin{array}{l}\text { Lung metastasis, } \\
\text { Mediastinal LN }\end{array}$ & 5 & 0 & 50 & Nivolumab & 6.3 & PR & $-78.5 \%$ \\
\hline 3 & 86 & M & Ad & Lung metastasis & 50 & 10 & 0 & Nivolumab & 10.5 & PR & $-73.2 \%$ \\
\hline 4 & 60 & M & Carcinosarcoma & Liver metastasis & 0 & 0 & 50 & Nivolumab & 8.2 & SD & $-10.8 \%$ \\
\hline 5 & 73 & M & Ad & Lung metastasis & 0 & 0 & 1 & Nivolumab & $2.6^{*}$ & SD & $-6.3 \%$ \\
\hline 6 & 66 & M & Ad & Mediastinal LN & 5 & 0 & 50 & Nivolumab & 3.7 & PD & $+34.3 \%$ \\
\hline 7 & 60 & M & $\mathrm{Sq}$ & Lung metastasis & 0 & 0 & 10 & Nivolumab & 6.7 & PD & $+39.4 \%$ \\
\hline 8 & 69 & M & Sq & Lung metastasis & 0 & 0 & 50 & Nivolumab & 6.4 & PD & $+42.0 \%$ \\
\hline 9 & 83 & M & $\mathrm{Sq}$ & Bone metastasis (Rib) & 50 & 0 & 50 & Nivolumab & 2.1 & PD & $+69.2 \%$ \\
\hline 10 & 62 & M & $\mathrm{Sq}$ & $\begin{array}{l}\text { Lung metastasis, } \\
\text { Mediastinal LN }\end{array}$ & 1 & 1 & 50 & Nivolumab & 2.9 & $\mathrm{PD}$ & $+144.7 \%$ \\
\hline
\end{tabular}

PD-L1: Programmed cell death-ligand 1; PD-L2: programmed cell death-ligand 2; PD-1: programmed cell death-1; PFS: progression-free survival; irRC: immune-related response criteria; Sq: squamous cell carcinoma; Ad: adenocarcinoma; LN: lymph node; PR: partial response; SD: stable disease; PD: progression disease. *PD reason: vertebral body invasion.

\section{Patients and Methods}

Patients and samples. From January 2015 to December 2017, 11 patients underwent complete resection of primary lung cancer at the Department of Surgery and Science, Graduate School of Medical Sciences, Kyushu University (Fukuoka, Japan). Among them, one patient who did not have a target lesion was excluded. Thus, the data of the remaining 10 patients were included in this retrospective study. The age, sex, histological type, target lesion, and type of anti-PD-1 drug were investigated. Clinical information was obtained from medical records. Nivolumab and Pembrolizumab were administered intravenously at a dose of $3 \mathrm{mg} / \mathrm{kg}$ every 2 weeks and $200 \mathrm{mg}$ every 3 weeks, respectively. Tumor response was evaluated by computed tomography every 6 to 8 weeks according to the immune-related response criteria (irRC) (12-15). The institutional review board approved this study (Kyushu University, IRB No. 29-261).

Immunohistochemical analysis of PD-L1 and PD-L2 expression. Formalin-fixed and paraffin-embedded tumor tissue sections were used to determine the expression of PD-L1 and PD-L2 in tumor tissue. The immunohistochemical analysis was conducted using antibodies against PD-L1 (clone 22C3, dilution 1:50; Agilent/Dako, Carpineteria, CA, USA), PD-L1 (clone SP142, dilution 1:100; Spring Bioscience, Ventana, Tucson, AZ, USA) and PD-L2 (clone 176611, dilution 1:200; R\&D systems, Inc., Minneapolis, MN, USA). Immunohistochemistry (IHC) for PD-L1 was performed as described previously (16-18). Regarding IHC for PD-L2, $4 \mu \mathrm{m}$ thick sections were mounted on glass slides with the use of the B Bond-III autostainer (Leica Microsystems, Newcastle, UK). Briefly, slices were treated with proteinase $\mathrm{K}$ (Agilent/Dako, Carpineteria, CA, USA) for $5 \mathrm{~min}$ and then incubated with anti-human PD-L2 antibody for $30 \mathrm{~min}$. This automated system used a Refine polymer detection system (Leica Microsystems, Newcastle, UK) with horseradish peroxidase-polymer as secondary antibody and 3,3' diaminobenzidine (DAB) as the chromogen. The slides were visualized using DAB.

The proportion of carcinoma cells positive for PD-L1 or PD-L2 was estimated as the percentage of total tumor cells in whole sections. All immunohistochemical images were evaluated independently by three investigators (S.T., K.T., and T.J.) who were unaware of the outcomes. In case the determinations were different among three observers, the slides were reviewed by all the three investigators together to reach consensus. We set the cut-off values of PD-L1 (22C3), PD-L1 (SP142), and PD-L2 positivity to $50 \%$ (4), $1 \%$ (6), and $50 \%$, respectively.

\section{Results}

Patient characteristics. This study included 10 patients who underwent curative lung resection and received anti-PD-1 drugs for recurrence. The patient characteristics are described in Table I. The median patient age was 69 years (range $=60-86$ years), and all patients were men. Half of the patients were diagnosed as having squamous cell carcinoma. Target lesions included lung, liver, lymph node, and bone metastases. Immunohistochemistry for PD-L1, using two different primary antibodies, and PD-L2 was performed and patients were classified into positive or negative expression as described in Methods. Two patients $(20.0 \%)$ were positive for PD-L1 expression as assayed using the $22 \mathrm{C} 3$ antibody, and two patients $(20.0 \%)$ were positive for PD-L1 expression as assessed using the SP142 antibody. Seven patients (70.0\%) were positive for PD-L2 expression. Nine patients $(90.0 \%)$ received nivolumab. The median progression-free survival was 6.3 months (range=2.1-10.5 months). Tumor response to antiPD-1 antibodies according to irRC included partial response (PR), stable disease (SD), and progressive disease (PD) in 3 , 2 , and 5 patients, respectively.

Association between PD-L2/PD-L1 expression and tumor response rate to anti-PD-1 drugs. The range of $\mathrm{PD}-\mathrm{L} 2$ positive expression was $0 \%, 1-4 \%, 10-49 \%$, and $\geq 50 \%$ in $1,1,1$, and 7 patients, respectively. Figure 1 shows waterfall plots for the 

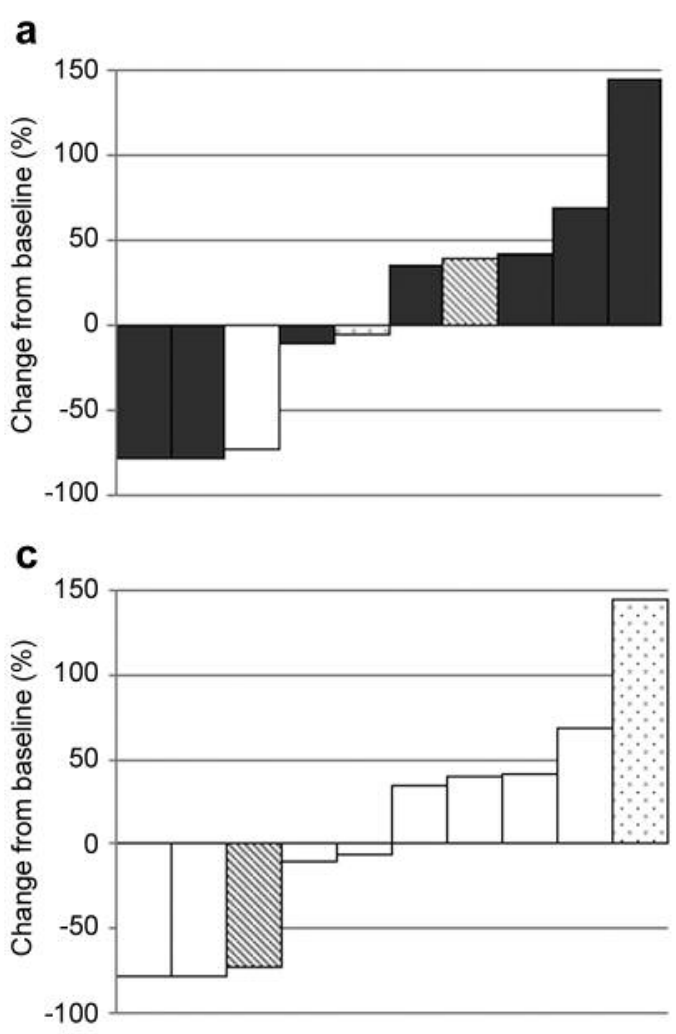

b
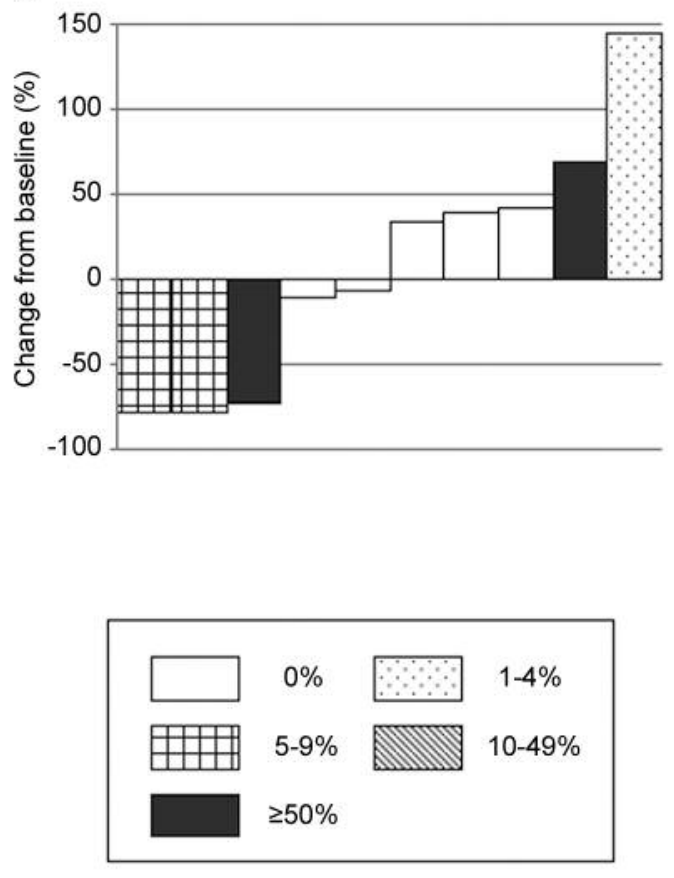

Figure 1. Waterfall plot for best percentage change from baseline in tumor measurement according to the expression of (a) programmed cell deathligand 2, (b) programmed cell death-ligand 1 (PD-L1; antibody clone 22C3), and (c) PD-L1 (antibody clone SP142).

best percentage change from baseline in tumor measurement according to the expression of PD-L2/PD-L1. In NSCLC patients positive for PD-L2 ( $\geq 50 \%), 2(28.6 \%), 1(14.3 \%)$, and $4(57.1 \%)$ of 7 tumors showed PR, SD, and PD, respectively. The tumor response rate to anti-PD-1 drugs was $28.6 \%(2 / 7)$ and $33.3 \%(1 / 3)$ in NSCLC patients positive for PD-L2 $(\geq 50 \%)$ and negative for PD-L2 $(<50 \%)$, respectively. In evaluating PD-L1 expression using 22C3, the tumor response rate was $50.0 \%(1 / 2)$ and $25.0 \%(2 / 8)$ in NSCLC patients positive for PD-L1 $(\geq 50 \%)$ and negative for PD-L1-negative $(<50 \%)$, respectively. Similarly, in evaluating PD-L1 positivity using SP142, the tumor response rate was $50.0 \%(1 / 2)$ and $25.0 \%$ $(2 / 8)$ in NSCLC patients positive for PD-L1 $(\geq 1 \%)$ and negative for $\mathrm{PD}-\mathrm{L} 1(<1 \%)$, respectively. These data are summarized in Table II. Of note, disease control (SD) was obtained in two patients despite PD-L1-negativity (22C3: 0\%; SP142: 0\%), and positivity for PD-L2 ( $\geq 1 \%)$.

\section{Discussion}

In the present study, tumor response rate to anti-PD-1 drugs was found to be $28.6 \%$ in NSCLC patients positive for PD-L2 ( $\geq 50 \%$ ). To the best of our knowledge, this is the first study to
Table II. The relationship between PD-L2/PD-L1 expression and response rate to anti-PD-1 drugs in patients with non-small cell lung cancer.

\begin{tabular}{lccc}
\hline $\begin{array}{l}\text { PD-L2/PD-L1 } \\
\text { expression }\end{array}$ & Response (+) & Response (-) & $\begin{array}{c}\text { Number of } \\
\text { patients }\end{array}$ \\
\hline PD-L2 $(176611) \geq 50 \%$ & $2(28.6 \%)$ & $5(71.4 \%)$ & 7 \\
PD-L2 $(176611)<50 \%$ & $1(33.3 \%)$ & $2(66.7 \%)$ & 3 \\
PD-L1 (22C3) $\geq 50 \%$ & $1(50.0 \%)$ & $1(50.0 \%)$ & 2 \\
PD-L1 (22C3) $<50 \%$ & $2(25.0 \%)$ & $6(75.0 \%)$ & 8 \\
PD-L1 (SP142) $\geq 1 \%$ & $1(50.0 \%)$ & $1(50.0 \%)$ & 2 \\
PD-L1 (SP142) $<1 \%$ & $2(25.0 \%)$ & $6(75.0 \%)$ & 8 \\
\hline
\end{tabular}

PD-L1: Programmed cell death-ligand 1; PD-L2: programmed cell death-ligand 2; PD-1: programmed cell death-1.

investigate the predictive role of PD-L2 expression to immunotherapy in patients with NSCLC, although the sample size was very small. Of note, disease control (SD) observed in 2 tumors with PD-L1-negativity and PD-L2-positivity suggesting that PD-L2 expression may have a clinical role as a target of immunotherapy (Figure 1). While the clinical significance of PD-L1 expression has been examined in many 
previous studies (19-26), that of PD-L2 has not been well investigate in NSCLC patients.

Recently, few studies have suggested the relationship between PD-L2 expression and clinical response to immunotherapy $(11,27)$. Yearley et al. reported that in patients with several kinds of solid malignancies treated by PD-1 axis targeted therapy, PD-L2 positivity was statistically significant predictor of progression-free survival, while PD-L1 was not (11). Given the results of CheckMate-057 that overall survival of anti-PD-1 drug administered patients with PD-L1 negativity was equivalent to that of patients treated by chemotherapy, the potential role of other PD-1 ligands except of PD-L1 may exist (3). As shown in Figure 1, two tumors with PD-L1-negativity and PD-L2-positivity showed SD to anti-PD-1 drugs, which may at least partly explain a positive clinical response to antiPD-1 antibodies in NSCLC patients negative for PD-L1. Because high PD-L2 positivity was observed in the current study (7/10), therapeutic strategies targeting PD-L2 would be of interest. The potential role of PD-L2 expression alone or in combination with PD-L1 expression as a predictive biomarker for the response to immunotherapy may need to be investigated in future prospective studies.

The present study had several limitations. First, this study did not analyze the influence of chemotherapy and radiotherapy on PD-L1 expression before administration of anti-PD-1 drugs due to the small sample size. Chemotherapy is reported to induce PD-L1 expression $(28,29)$, and our previous studies suggested that radiotherapy may contribute to the conversion of PD-L1-negative into PD-L1 positive NSCLC (30-32). Thus, further analyses including therapy-derived effects are necessary to draw definitive conclusions. Second, PD-L1 and PD-L2 expression was examined using only 22C3, SP142 and 176611 antibody clones. The positive rate of PDL1 using SP142 was reported to be lower than that of other antibodies such as 28-8 and SP263 (33). However, according to a previous study of patients with small-cell lung cancer, SP142-positivity was higher than that of other antibodies (34). Therefore, both of PD-L1 and PD-L2 expression should be evaluated using additional antibodies.

In conclusion, our study demonstrated that PD-L2 expression may be a target of anti-PD-1 drugs in NSCLC patients negative for PD-L1. The potential role of PD-L2 expression as a predictive biomarker for the response to immunotherapy needs to be elucidated in future studies.

\section{Conflicts of Interest}

All the Authors declare no conflicts of interest.

\section{References}

1 Torre LA, Bray F, Siegel RL, Ferlay J, Lortet-Tieulent J and Jemal A: Global cancer statistics, 2012. CA Cancer J Clin 65: 87$108,2015$.
2 Ettinger DS, Akerley W, Bepler G, Blum MG, Chang A, Cheney RT, Chirieac LR, D'Amico TA, Demmy TL, Ganti AK, Govindan R, Grannis FW, Jr., Jahan T, Jahanzeb M, Johnson DH, Kessinger A, Komaki R, Kong FM, Kris MG, Krug LM, Le QT, Lennes IT, Martins R, O'Malley J, Osarogiagbon RU, Otterson GA, Patel JD, Pisters KM, Reckamp K, Riely GJ, Rohren E, Simon GR, Swanson SJ, Wood DE, Yang SC and Members NNSCLCP: Non-small cell lung cancer. J Natl Compr Canc Netw 8: 740-801, 2010.

3 Borghaei H, Paz-Ares L, Horn L, Spigel DR, Steins M, Ready NE, Chow LQ, Vokes EE, Felip E, Holgado E, Barlesi F, Kohlhaufl M, Arrieta O, Burgio MA, Fayette J, Lena H, Poddubskaya E, Gerber DE, Gettinger SN, Rudin CM, Rizvi N, Crino L, Blumenschein GR Jr., Antonia SJ, Dorange C, Harbison CT, Graf Finckenstein F and Brahmer JR: Nivolumab versus docetaxel in advanced nonsquamous non-small-cell lung cancer. N Engl J Med 373: 1627-1639, 2015.

4 Reck M, Rodriguez-Abreu D, Robinson AG, Hui R, Csoszi T, Fulop A, Gottfried M, Peled N, Tafreshi A, Cuffe S, O'Brien M, Rao S, Hotta K, Leiby MA, Lubiniecki GM, Shentu Y, Rangwala $\mathrm{R}$ and Brahmer JR: Pembrolizumab versus Chemotherapy for PD-L1-Positive Non-Small-Cell Lung Cancer. N Engl J Med 375: 1823-1833, 2016.

5 Sacher AG and Gandhi L: Biomarkers for the clinical use of PD1/PD-L1 inhibitors in non-small-cell lung cancer: A Review. JAMA Oncol 2: 1217-1222, 2016.

6 Takada K, Okamoto T, Shoji F, Shimokawa M, Akamine T, Takamori S, Katsura M, Suzuki Y, Fujishita T, Toyokawa G, Morodomi Y, Okano S, Oda Y and Maehara Y: Clinical significance of PD-L1 protein expression in surgically resected primary lung adenocarcinoma. J Thorac Oncol 11: 1879-1890, 2016.

7 Takada K, Toyokawa G, Okamoto T, Shimokawa M, Kozuma Y, Matsubara T, Haratake N, Akamine T, Takamori S, Katsura M, Shoji F, Oda Y and Maehara Y: A comprehensive analysis of programmed cell death ligand-1 expression with the clone SP142 antibody in non-small-cell lung cancer patients. Clin Lung Cancer 18: 572-582.e571, 2017.

8 Takada K, Toyokawa G, Shoji F, Okamoto T and Maehara Y: The significance of the PD-L1 expression in non-small-cell lung cancer: Trenchant double swords as predictive and prognostic markers. Clin Lung Cancer 19: 120-129, 2018.

9 Keir ME, Butte MJ, Freeman GJ and Sharpe AH: PD-1 and its ligands in tolerance and immunity. Ann Rev Immunol 26: 677704, 2008.

10 Latchman Y, Wood CR, Chernova T, Chaudhary D, Borde M, Chernova I, Iwai Y, Long AJ, Brown JA, Nunes R, Greenfield EA, Bourque K, Boussiotis VA, Carter LL, Carreno BM, Malenkovich N, Nishimura H, Okazaki T, Honjo T, Sharpe AH and Freeman GJ: PD-L2 is a second ligand for PD-1 and inhibits T cell activation. Nature Immunol 2: 261-268, 2001.

11 Yearley JH, Gibson C, Yu N, Moon C, Murphy E, Juco J, Lunceford J, Cheng J, Chow LQM, Seiwert TY, Handa M, Tomassini JE and McClanahan T: PD-L2 Expression in human Tumors: Relevance to Anti-PD-1 therapy in cancer. Clin Cancer Res 23: 3158-3167, 2017.

12 Adra N, Einhorn LH, Althouse SK, Ammakkanavar NR, Musapatika D, Albany C, Vaughn D and Hanna NH: Phase II trial of pembrolizumab in patients with platinum refractory germ-cell tumors: a Hoosier Cancer Research Network Study GU14-206. Ann Oncol 29: 209-214, 2018.

13 Chesney J, Puzanov I, Collichio F, Singh P, Milhem MM, Glaspy J, Hamid O, Ross M, Friedlander P, Garbe C, Logan TF, 
Hauschild A, Lebbe C, Chen L, Kim JJ, Gansert J, Andtbacka RHI and Kaufman HL: Randomized, open-label phase II study evaluating the efficacy and safety of talimogene laherparepvec in combination with ipilimumab versus ipilimumab alone in patients with advanced, unresectable melanoma. J Clin Oncol 36: 1658$1667,2017$.

14 Haag GM, Zoernig I, Hassel JC, Halama N, Dick J, Lang N, Podola L, Funk J, Ziegelmeier C, Juenger S, Bucur M, Umansky L, Falk CS, Freitag A, Karapanagiotou-Schenkel I, Beckhove P, Enk A and Jaeger D: Phase II trial of ipilimumab in melanoma patients with preexisting humoural immune response to NY-ESO1. Eur J Cancer 90: 122-129, 2018.

15 Tanizaki J, Haratani K, Hayashi H, Chiba Y, Nakamura Y, Yonesaka K, Kudo K, Kaneda H, Hasegawa Y, Tanaka K, Takeda M, Ito A and Nakagawa K: Peripheral blood biomarkers associated with clinical outcome in non-small cell lung cancer patients treated with nivolumab. J Thorac Oncol 13: 97-105, 2018.

16 Takada K, Okamoto T, Toyokawa G, Kozuma Y, Matsubara T, Haratake N, Akamine T, Takamori S, Katsura M, Shoji F, Oda Y and Maehara Y: The expression of PD-L1 protein as a prognostic factor in lung squamous cell carcinoma. Lung Cancer 104: 7-15, 2017.

17 Takada K, Toyokawa G, Tagawa T, Kohashi K, Shimokawa M, Akamine T, Takamori S, Hirai F, Shoji F, Okamoto T, Oda Y and Maehara Y: PD-L1 expression according to the EGFR status in primary lung adenocarcinoma. Lung Cancer 116: 1-6, 2018.

18 Toyokawa G, Takada K, Haratake N, Takamori S, Akamine T, Katsura M, Fujishita T, Shoji F, Okamoto T, Oda Y and Maehara Y: Favorable disease-free survival associated with programmed death ligand 1 expression in patients with surgically resected small-cell lung cancer. Anticancer Res 36: 4329-4336, 2016.

19 Takada K, Okamoto T, Tominaga M, Teraishi K, Akamine T, Takamori S, Katsura M, Toyokawa G, Shoji F, Okamoto M, Oda Y, Hoshino T and Maehara Y: Clinical implications of the novel cytokine IL-38 expressed in lung adenocarcinoma: Possible association with PD-L1 expression. PloS One 12: e0181598, 2017.

20 Takada K, Toyokawa G, Okamoto T, Baba S, Kozuma Y, Matsubara T, Haratake N, Akamine T, Takamori S, Katsura M, Shoji F, Honda H, Oda Y and Maehara Y: Metabolic characteristics of programmed cell death-ligand 1-expressing lung cancer on (18) F-fluorodeoxyglucose positron emission tomography/computed tomography. Cancer Med 6: 2552-2561, 2017.

21 Takada K, Toyokawa G, Tagawa T, Kohashi K, Akamine T, Takamori S, Hirai F, Shoji F, Okamoto T, Oda Y and Maehara Y: Association between PD-L1 expression and metabolic activity on (18)F-FDG PET/CT in patients with small-sized lung cancer. Anticancer Res 37: 7073-7082, 2017.

22 Haratake N, Toyokawa G, Takada K, Kozuma Y, Matsubara T, Takamori S, Akamine T, Katsura M, Shoji F, Okamoto T, Oda Y and Maehara Y: Programmed death-ligand 1 expression and EGFR mutations in multifocal lung cancer. Ann Thorac Surg 105: 448-454, 2018.

23 Toyokawa G, Takada K, Okamoto T, Kawanami S, Kozuma Y, Matsubara T, Haratake N, Takamori S, Akamine T, Katsura M, Yamada Y, Shoji F, Baba S, Kamitani T, Oda Y, Honda H and Maehara Y: Relevance between programmed death ligand 1 and radiologic invasiveness in pathologic stage I lung adenocarcinoma. Ann Thorac Surg 103: 1750-1757, 2017.

24 Toyokawa G, Takada K, Okamoto T, Shimokawa M, Kozuma Y, Matsubara T, Haratake N, Takamori S, Akamine T, Katsura M, Shoji F, Oda Y and Maehara Y: Computed tomography features of lung adenocarcinomas with programmed death ligand 1 expression. Clin Lung Cancer 18: e375-e383, 2017.

25 Toyokawa G, Takada K, Okamoto T, Kozuma Y, Matsubara T, Haratake N, Takamori S, Akamine T, Katsura M, Shoji F, Oda Y and Maehara Y: High frequency of programmed death-ligand 1 expression in emphysematous bullae-associated lung adenocarcinomas. Clin Lung Cancer 18: 504-511.e501, 2017.

26 Akamine T, Takada K, Toyokawa G, Kinoshita F, Matsubara T, Kozuma Y, Haratake N, Takamori S, Hirai F, Tagawa T, Okamoto T, Yoneshima Y, Okamoto I, Shimokawa M, Oda Y, Nakanishi Y and Maehara Y: Association of preoperative serum CRP with PDL1 expression in 508 patients with non-small cell lung cancer: A comprehensive analysis of systemic inflammatory markers. Sur Oncol 27: 88-94, 2018.

27 Ahmad SM, Martinenaite E, Holmstrom M, Jorgensen MA, Met O, Nastasi C, Klausen U, Donia M, Pedersen LM, Munksgaard L, Odum N, Woetmann A, Svane IM and Andersen MH: The inhibitory checkpoint, PD-L2, is a target for effector T cells: Novel possibilities for immune therapy. Oncoimmunol 7: e1390641, 2018.

28 Kuczynski EA, Krueger J, Chow A, Xu P, Man S, Sundaravadanam Y, Miller JK, Krzyzanowski PM and Kerbel RS: Impact of chemical-induced mutational load increase on immune checkpoint therapy in poorly responsive murine tumors. Mol Cancer Ther 17: 869-882, 2018.

29 Haratake N, Toyokawa G, Tagawa T, Kozuma Y, Matsubara T, Takamori S, Akamine T, Yamada Y, Oda Y and Maehara Y: Positive conversion of PD-L1 expression after treatments with chemotherapy and nivolumab. Anticancer Res 37: 5713-5717, 2017.

30 Takamori S, Toyokawa G, Okamoto I, Takada K, Kinoshita F, Kozuma Y, Matsubara T, Haratake N, Akamine T, Mukae N, Hirai F, Tagawa T, Oda Y, Iwaki T, Iihara K, Nakanishi Y and Maehara Y: Clinical significance of PD-L1 expression in brain metastases from non-small cell lung cancer. Anticancer Res 38: 553-557, 2018.

31 Takamori S, Toyokawa G, Okamoto I, Takada K, Kozuma Y, Matsubara T, Haratake N, Akamine T, Katsura M, Mukae N, Shoji F, Okamoto T, Oda Y, Iwaki T, Iihara K, Nakanishi Y and Maehara Y: Discrepancy in programmed cell death-ligand 1 between primary and metastatic non-small cell lung cancer. Anticancer Res 37: 4223-4228, 2017.

32 Takamori S, Toyokawa G, Takada K, Shoji F, Okamoto T and Maehara Y: Combination therapy of radiotherapy and anti-PD1/PD-L1 treatment in non-small-cell lung cancer: A mini-review. Clin Lung Cancer 19: 12-16, 2017.

33 Rimm DL, Han G, Taube JM, Yi ES, Bridge JA, Flieder DB, Homer R, West WW, Wu H, Roden AC, Fujimoto J, Yu H, Anders R, Kowalewski A, Rivard C, Rehman J, Batenchuk C, Burns V, Hirsch FR and Wistuba II: A prospective, multiinstitutional, pathologist-based assessment of 4 immunohistochemistry assays for PD-L1 expression in non-small cell lung cancer. JAMA Oncol 3: 1051-1058, 2017.

34 Takada K, Toyokawa G, Okamoto T, Akamine T, Takamori S, Katsura M, Fujishita T, Shoji F, Oda Y and Maehara Y: An immunohistochemical analysis of PD-L1 protein expression in surgically resected small cell lung cancer using different antibodies and criteria. Anticancer Res 36: 3409-3412, 2016.

Received August 31, 2018

Revised September 12, 2018

Accepted September 13, 2018 